\title{
Molecular Analysis of Alternative Transcripts of CCDC94 Gene in the Brain Tissues of Rhesus Monkey
}

\author{
Se-Eun Yun, Kung Ahn and Heui-Soo Kim* \\ Department of Biological Sciences, College of Natural Sciences, Pusan National University, Busan 609-735, Korea
}

Received March 14, 2011/Accepted March 17, 2011

\begin{abstract}
The genome of the rhesus monkey has diverged as an average sequence identity of $\sim 93 \%$. The rhesus monkey has been widely used as a non-human primate in the field of biomedical and evolutional research. Insertion of transposable elements (TEs) induced several events such as transcriptional diversity and different expression in host genes. In this study, 112 transcripts were identified from a full-length cDNA library of brain tissues of the rhesus monkey. One transcript (R54) showed a different expression pattern between human and rhesus monkey tissues. This phenomenon can be an explanation that R54 transcript was acquired by splicing a donor site derived from exonization of the L2A element. Therefore, integration of TEs during primate radiation could contribute to transcriptional diversity and gene regulation.
\end{abstract}

Key words : Rhesus monkey, brain cDNA library, CCDC94, gene expression, alternative splicing, primates

\section{서 론}

Junk DNA라고 알려져 왔던 유전자 이외의 영역은 Babara McClintock에 의해 옥수수에서 'jumping gene'라고 짐작했던 트랜스포존(transposon)이 밝혀짐으로써, 그들의 기능 및 역 할의 연구가 가속화되었다[24]. 이들의 특징은 미생물을 비롯 한 식물, 동물의 유전체 내에 산재하여[19], 종의 특징을 구분 짓는 표지 역할을 하며[2], 직접적으로 발현함으로써 단백질로 번역되어 개체에게 질병을 야기하거나[1,3,5,22,26,29], 반대로 개체에게 이로운 역할을 하는 것으로 알려져 왔다[1]. 그들 서 열의 특징인 반복적인 염기배열은 유전자 재배열을 통한 유전 체 교란을 야기 하고[7,8,10,13], 스플라이싱 사이트를 제공하 여 다양한 전사산물들의 생성한다. 주목 할 만한 것은 트랜스 포존이 유전자의 5'UTR에 끼어 들어가, 트랜스포존 스스로가 가진 프로모터에 의해 유전자의 전사를 촉진시킬 수 있으며 [6,21], 3'UTR에 끼어들어가 poly adenylation 신호를 제공할 수 있음이 밝혀 졌다[30]. 인간 유전체 염기서열이 완성된 이 후, 유전자의 생물학적 기능과 유전질환의 원인규명은 현재까 지 끓임없이 밝혀지고 있으며[16,18,28], 더 나아가 인간을 대 신 할 모델동물을 이용하여, 유전적인 현상과 질환을 해석하 려는 노력은 인간과 가장 유사한 종에서 시도 되고 있다. 더욱 이 영장류와 같은 원숭이를 이용한 유전체 비교 연구는 유전 체를 진화학적으로 해석할 수 있어[9,12,15], 다양한 유전체 내 의 이벤트들의 원인과 시기를 해석할 수 있기 때문에, 오늘날

*Corresponding author

Tel : +82-51-581-2962, Fax : +82-51-510-2259

E-mail : khs307@pusan.ac.kr
활발하게 연구가 진행되고 있다. 현재 침팬지 유전체는 2006 년에 공개 되었으며[4], 붉은 털 원숭이의 경우 2006년도 유전 체 초안이 공개 되었다[17]. 오랑우탄 유전체 역시 2007년도에 유전체 초안이 공개 되었다[23]. 이 가운데 붉은 털 원숭이는 인간과 형태학적, 생리학적, 유전학적으로 가장 유사한 종 중 가장 많이 연구되는 영장류 중 하나이며, 생물의학적으로 적 합한 실험 모델로서 보고되고 있다[11]. 본 연구에서는, 붉은 털 원숭이 뇌 조직의 $\mathrm{cDNA}$ 라이브러리를 구축하였으며, 이를 통하여 밝혀 지지 않은 전사체의 동정 및 트랜스포존이 삽입 되어 형성된 융합 전사체에 대한 구조적인 특징 분석, 유전적 발현 및 진화적인 분석을 고찰하였다.

\section{재료 및 방법}

붉은 털 원숭이의 뇌 조직 $\mathrm{CDNA}$ 라이브러리 구축

붉은 털 원숭이의 뇌 조직에서의 $\mathrm{cDNA}$ 라이브러리는 cap trapper method를 사용하여 구축하였으며, 라이브러리 스크리닝을 위하여 클로닝 벡터(pCNS-D2) 양쪽의 서열로부 터 Primer쌍 preT7 (5'-CGT GTA CGG TGG GAG GTC TA-3')와 SP6 (5'-CCT ATT CTA TAG TGT CAC CTA AAT-3')을 디자인하여 PCR을 통해 스크리닝 한 다음, pos$^{-}$ itive 클론은 Competent cell에 LB 배지에서 배양하였다.

\section{$\mathrm{CCDC94}$ 전사체에서 전위요소분석}

CCDC94 유전자의 염기서열은 UCSC genome browser (http://genome.ucsc.edu/)의 BLAT (Basic local alignment tool)을 이용하여 분석하였으며, 라이브러리를 통해 밝혀진 전 
사체 내에 삽입된 전위요소 서열의 분석을 위하여 RepeatMasker 프로그램을 사용 하였다(http://repeatmasker. genome.washington.edu).

\section{Total RNA분리}

또한 붉은 털 원숭이 뇌 조직의 $\mathrm{cDNA}$ 라이브러리를 통해 동정된 CCDC94 유전자의 붉은 털 원숭이 내에서의 전사 양상 및 전사의 특징과 인간과의 비교 분석을 위하여 붉은 털 원숭 이의 조직 $(1$, 부신; 2 , 소뇌; 3 , 대뇌피질; 4 , 심장; 5 , 신장; 6 , 간; 7 , 폐; 8 , 고환; 9 , 골격근; 10 , 기관; 11 , 비장; 12 , 결장; 13 , 맹장; 14 , 위; 15 , 췌장; 16 , 타액선; 17 , 직장; 18 , 방광; 19 , 십이지 장; 20, 공장에서 RNeasy mini kit (Qiagen)을 이용하여 total $\mathrm{RNA}$ 를 분리하였다. 인간 조직, 1 .부신; 2 , 소뇌; 3 , 전 뇌; 4 , 심장; 5 , 신장; 6 , 간; 7 , 폐; 8 , 고환; 9 , 기관; 10 , 골수; 11 , 태아 뇌; 12 , 태아 간; 13 , 태반; 14 , 전립선; 15 , 타액선; 16 , 골격근; 17 , 척수; 18 , 흉선; 19 , 갑상선; 20 , 골수 유래의 total RNA는 Clontech사로부터 구매하였다.

\section{$\mathrm{PCR}$ 과 RT-PCR 증폭}

붉은 털 원숭이 뇌조직으로부터 확립한 full-length cDNA library에서 찾아낸 각 전사체를 인간 및 영장류 $\mathrm{ge}^{-}$ nomic DNA를 사용하여 각 전사체의 가동성인자의 삽입시 기 분석을 위해 $\mathrm{PCR}$ 증폭을 하였다. 이들의 프라이머 정보 는 Table 1 에서 보여준다. $\mathrm{PCR}$ 분석은 $94^{\circ} \mathrm{C}$ 에서 $4 \mathrm{~min}, 35$ cycle로 $94^{\circ} \mathrm{C}$ 에서 $40 \mathrm{sec}, 55^{\circ} \mathrm{C}$ 에서 $40 \mathrm{sec}, 72^{\circ} \mathrm{C}$ 에서 $3 \mathrm{~min}$ 에서 수행하였다. 추출한 $\mathrm{RNA}$ 는 $\mathrm{cDNA}$ 합성을 위해 DNA-free RNA를 사용했으며, M-MLV (moloney- murine leukemia virus) 역전사 효소(Promega)와 RNase inhibitor (Promega)를 사용하여 합성하였다. 새롭게 찾아낸 각 전사 체의 조직 발현을 보기 위해 RT-PCR 증폭을 하였다. 각 유 전자들의 프라이머 정보는 Table 1 에서 보여준다. RT-PCR 분석은 $94^{\circ} \mathrm{C}$ 에서 $4 \mathrm{~min}, 35$ cycle로 $94^{\circ} \mathrm{C}$ 에서 $40 \mathrm{sec}, 5$ $5{ }^{\circ} \mathrm{C} 58^{\circ} \mathrm{C}$ 에서 $40 \mathrm{sec}, 72^{\circ} \mathrm{C}$ 에서 $3 \mathrm{~min}$ 에서 수행하였다. Positive control로서는 housekeeping 유전자인 $\mathrm{G} 3 \mathrm{PDH}$ (glyceradehydes-3-phosphate dehydrogenase)를 이용하였 으며, 프라이머 G3PDH-S (GAA ATC CCA TCA CCA TCT TCC AGG)와 G3PDH-AS (GAG CCC CAG CCT TCT $\mathrm{CCA} \mathrm{TG}$ )를 사용해 $\mathrm{G} 3 \mathrm{PDH}$ 를 증폭하였다.

\section{결과 및 고찰}

붉은 털 원숭이의 뇌 유래의 $\mathrm{cDNA}$ 라이브러리를 통해 발 견된 $\mathrm{R} 54$ 전사체를 인간과 침팬지의 등록된 $\mathrm{mRNA}$ 서열 alignmnent를 통하여 비교 분석하였다. 원숭이에서는 인간의 4 번 엑손이 존재하지 않은 반면에 LINE 가운데 오래된 패밀리 가운데 하나인 L2A의 엑손화 현상으로 인하여, 인간에서는 존재 하지 않는 7번 엑손이 붉은 털 원숭이 R54 전사체에서 발견되었다(Fig. 1).

붉은 털 원숭이에서 L2A서열을 가진 R54 전사체와 L2A 서열이 존재하지 않는 인간의 전사체의 발현 양상을 비교하 기 위하여, 붉은 털 원숭이의 6 번과 8 번 엑손에 해당하는 영 역에서 프라이머(Table 1)를 디자인하여 인간과 붉은 털 원 숭이의 조직에서 RT-PCR을 수행하였다. 그 결과 인간의 조 직에서는 $\mathrm{L} 2 \mathrm{~A}$ 의 서열이 빠진 길이 $(150 \mathrm{bp})$ 의 전사체가 전

Table 1. Primer pair for expression comparison in human and rhesus tissues

\begin{tabular}{llc}
\hline Primers & Sequences $\left(5^{\prime}-3^{\prime}\right)$ & \\
\hline R54-R-2S & 5'-GGT GCT TGC GAG GTG ATT AG-3' & NM018074 \\
R54-R-2AS & 5'-GCA GGG GTC CTA AGA GGG-3' & \\
R54-R-3S & 5'-CCA GAA AGC GAA GAC TGC TG-3’ & \\
R54-R-3AS & 5'-CAA CGC TCT GCT CCC AGA C-3' \\
\hline
\end{tabular}
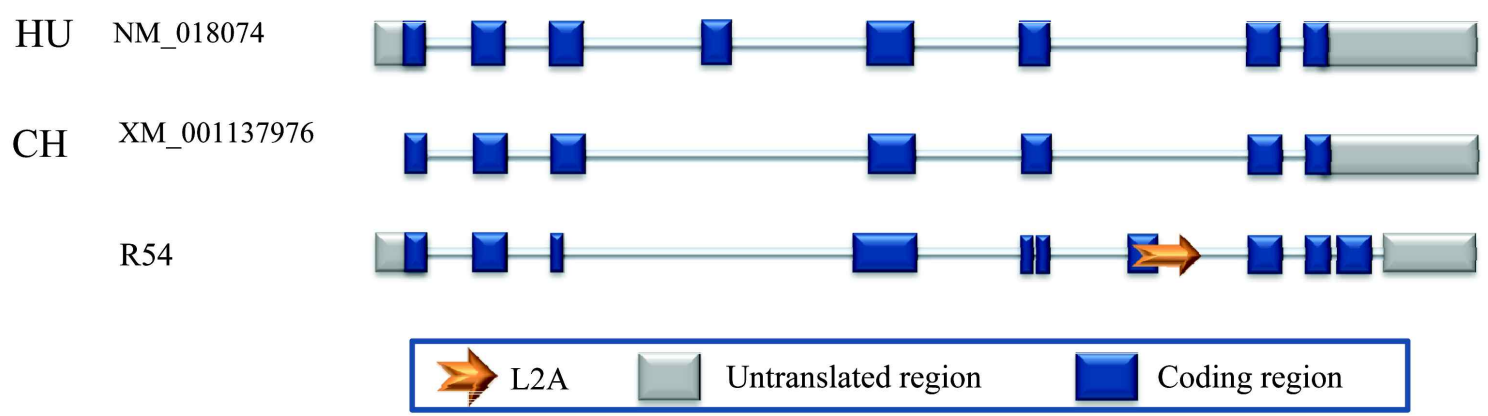

Fig. 1. The structure comparison with CCDA94 mRNA of human and chimpanzee in monkey R54 transcript. The arrow indicate L2A transposable element and boxes indicates exons. 
조직에서 발현하였으며(Fig. 2A), 특히 흥미롭게도, 인간 DNA에서 reference sequence로 등록되어 있는 것과는 달리 $\mathrm{L} 2 \mathrm{~A}$ 서열이 존재하는 길이 $(324 \mathrm{bp})$ 의 전사체가 몇몇의 조 직(Kidney, Liver, Fetal liver, Placenta, Prostate, Salivery gland, SK-muacle, Spinal cord, Thymus,and Thyroid gland) 특이적으로 발현되는 것을 확인하였다. 또한 붉은 털 원숭이 조직에서의 발현을 비교해 본 결과 전 조직에서 발 현하며, 몇몇의 조직에서는 강하게 발현하는 것을 확인할 수 있었다(Fig. 2B). 그러므로, 붉은 털 원숭이를 비롯한 인 간의 $C C D C 94$ 유전자의 경우, 붉은 털 원숭이의 7번 엑손에 해당하는 영역의 $\mathrm{L} 2 \mathrm{~A}$ 의 삽입은 $\mathrm{L} 2 \mathrm{~A}$ 의 내부의 서열에 의해 alternative splicing을 야기하여 대체 전사체가 조직 특이적 인 발현을 야기하는 것으로 추측된다(Fig. 3).

EST (Expressed Sequence Tags)와 cDNA와 genomic DNAs의 비교분석은 cassette exon을 포함한 alternative splicing 을 예상할 수 있다. 인간과 마우스 사이에서 잘 보존 되어 있지 않은 alternatively spliced exons이 나타날 확률이 잘 보존된 alternatively spliced exons이 나타날 확률보다 세 배 더 높은 것으로 보고 되고 있으며[31], 불규칙한 splicing으 로 부터 형성된 잘 보존되어 있지 않은 대부분의 alternative spliced exons은 기능을 하지 않는 것으로 보이나 그들의 진 화적인 역할은 중요함에 틀림없다. 새로운 스플라이싱 전사 체는 각 조직에 있어 긍정적인 효과(positive effect)를 가져올
수 있으며 진화 과정 동안 고정된다. 예를 들면 $A D A R B 1$ 유전 자의 $A l u$ 유래의 exon은 진화과정 동안 인트론에 삽입되어 새 로운 alternative spliced exon으로 고정되었다[20]. 이러한 엑 손들은 새로운 단백질을 생성하기 위한 driving force로 작용 하여, 진화과정 동안 종 분화를 촉진하는 역할을 할 수 있다. 따라서, 유전자의 암호화 서열 영역(coding sequence region) 에서의 이러한 이벤트는 진화 과정 동안의 조직 특이성과 같 은 다른 기능들에 있어서의 다양성의 획득뿐만 아니라, 도메 인의 변화에 따른 유전자 기능에 영향을 미칠 수 있다 [27,31,32]. 더불어 이러한 이벤트에 따른 기능의 변화는 때때 로 질병 및 위 유전자화(psuedogenization)를 야기할 수도 있 다[25].

새롭게 밝혀낸 붉은 털 원숭이의 R54 전사체는 인간 CCDC94 (coiled-coil domain containing 94) 유전자와 높은 유사성을 가진다. CCDC94 유전자는 혈액 응고와 더불어 세포 분열과 세포 성장에 관여하는 전사인자로 알려져 왔으며[14], 많은 서브패밀리를 가진 $C C D C$ 유전자 가운데 $C C D C 134$ 유전 자는 세포 안으로 유사분열물질(mitogen)을 활성화시키는 메 커니즘으로 대부분 세포 성장을 촉진시키는 유전자로서 다양 한 조직에서 발현하는 것으로 보고되었다[15]. CCDC98 유전 자의 경우에는 유방암 조직에서 발현하는 유전자로 알려져 있다[28]. 이처럼 인간의 $C C D C$ 유전자의 많은 서브패밀리 유 전자들은 조직 특이적 혹은 다양한 조직에서 발현하여 개체의

(A)

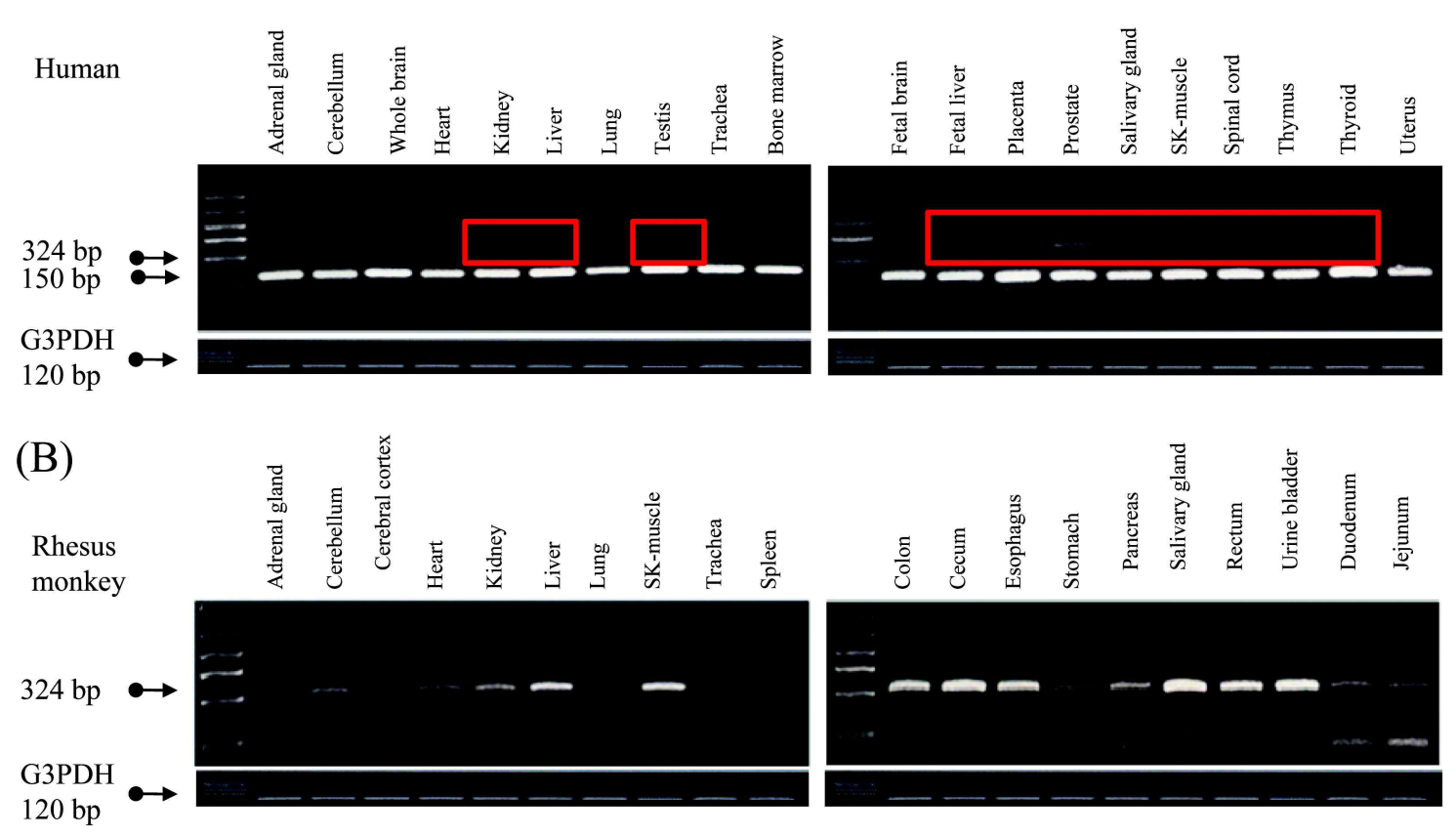

Fig. 2. Expression comparison of region contained L2A-derived exon in human and rhesus monkey tissues by RT-PCR amplification. Blank boxes indicate the products of different transcripts. (A) The expression pattern of region contained L2A-derived exon in human tissues. (B) The expression pattern of region contained L2A-derived exon in rhesus monkey tissues. 


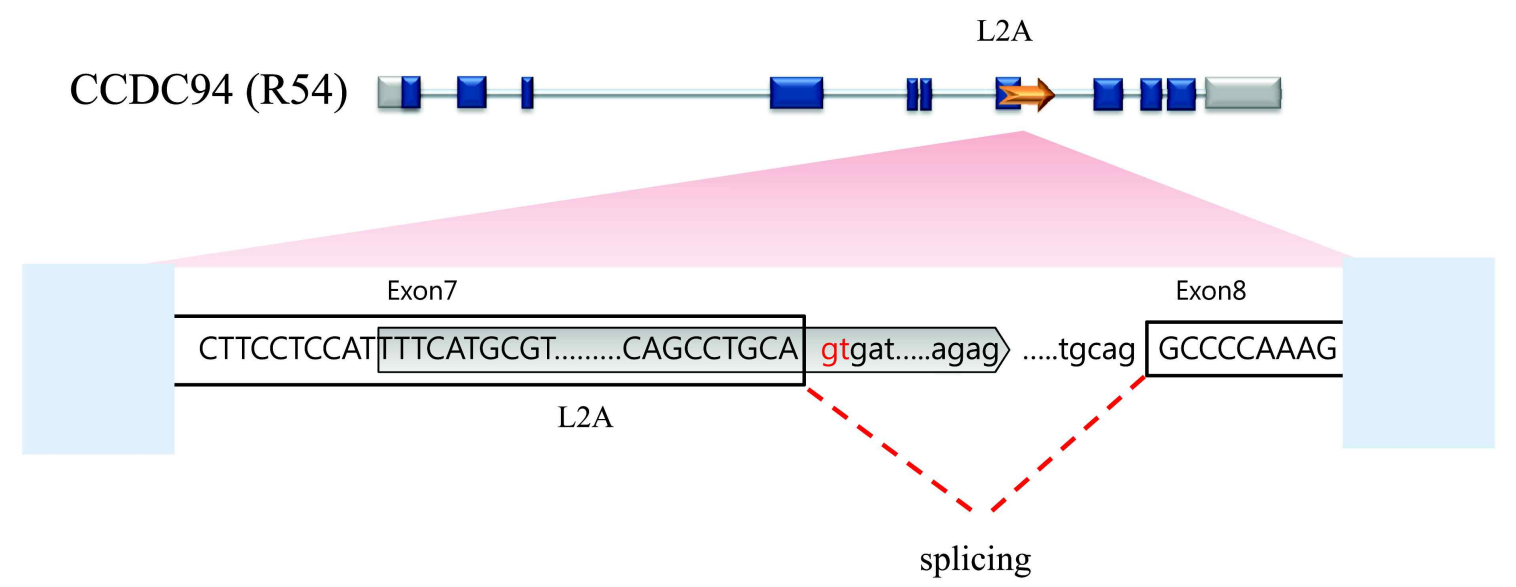

Fig. 3. Schematic structure of alternative spliced exon by insertion of L2A in R54 transcript. Grey box indicate L2A and blank boxes indicates exons in the lower figure. A dotted line indicate splicing site provided by L2A element.

생존에 관여하는 것으로 알려져 있다.

본 연구를 정리하면, 붉은 털 원숭이의 $\mathrm{cDNA}$ 라이브러리 를 통하여 R54 전사체 내에 LINE 패밀리인 L2A가 붉은 털 원숭이의 7번 엑손에 삽입되어 엑손화 된 현상을 밝혔다. CCDC94 유전자와 높은 유사성을 가진 $\mathrm{R} 54$ 전사체는 인간과 붉은 털 원숭이의 조직에서 서로 다른 양상의 유전자의 발현 을 보였다. 이러한 연구결과들은 가동성 유전인자의 삽입으로 인하여, 다양한 전사체를 야기시켜, 서로 다른 조직에서 생물 학적인 기능을 수행하는 것으로 시사된다.

\section{감사의 글}

이 논문은 부산대학교 자유과제 학술연구비(2년)에 의하여 연구되었으므로 이에 감사를 드립니다.

\section{References}

1. Bannert, N. and R. Kruth. 2006. The evolutionary dynamics of human endogenous retroviral familes. Annu. Rev. Genomics Hum. Genet. 7, 149-173.

2. Batzer, M. A. and P. L Deininger. 2002. Alu repeats and human genomic diversity. Nat. Rev. Genet. 3, 370-379.

3. Blikstad, V., F. Benachenhou, G. O. Sperber, and J. Blomberg. 2008. Evolution of human endogenous retroviral sequences: a conceptual account. Cell Mol. Life Sci. 65, 3348-3365.

4. Chimpanzee Sequencing and Analysis Consortium. 2005. Initial sequence of the chimpanzee genome and comparison with the human genome. Nature 437, 69-87.

5. Depil, S., C. Roche, P. Dussart, and L. Prin. 2002. Expression of a human endogenous retrovirus, HERV-K, in the blood cells of leukemia patients. Leukemia 16, 254-259.

6. Dunn, C. A., L. N. van de Lagemaat, G. J. Baillie, and D. L. Mager. 2005. Endogenous retrovirus long terminal re- peats as ready-to-use mobile promoters: the case of primate beta3GAL-T5. Gene 364, 2-12.

7. Flint, J., J. Rochette, C. F. Craddock, C. Dod, B. Vignes, S. W. Horsley, L. Kearney, V. J. Buckle, H. Ayyub, and D. R. Higgs. 1996. Chromosomal stabilisation by a subtelomeric rearrangement involving two closely related Alu elements. Hum. Mol. Genet. 5, 1163-1169.

8. Gogvadze, E. and A. Buzdin. 2009. Retroelements and their impact on genome evolution and functioning. Cell Mol. Life Sci. 66, 3727-3742.

9. Golub, M. S. 2010. Recent studies of iron deficiency during brain development in nonhuman primates. Biofactors 36, 111-116.

10. Goodier, J. L. and H. H. Jr. Kazazian. 2008. Retrotransposons revisited: the restraint and rehabilitation of parasites. Cell 135, 23-35.

11. Hadjiargyrou, M., M. F. Halsey, W. Ahrens, E. P. Rightmire, K. J. McLeod, and C. T. Rubin. 1998. Cloning of a novel cDNA expressed during the early stages of fracture healing. Biochem. Biophys. Res. Commun. 249, 879-884.

12. Hayreh, S. S. and J. B. Jonas. 2000. Ophthalmoscopic detectability of the parafoveal annular reflex in the evaluation of the optic nerve: an experimental study in rhesus monkeys. Ophthalmology 107, 1009-1014.

13. Hsu, C. H., Y. Zhang, and R. C. Hardison. 2010. An effective method for detecting gene conversion events in whole genomes. J. Comput. Biol. 17, 1281-1297.

14. Huang, J., T. Shi, T. Ma, Y. Zhang, X. Ma, Y. Lu, Q. Song, W. Liu, D. Ma, and X. Qiu. 2009. CCDC134, a novel secretory protein, inhibits activation of ERK and JNK, but not p38 MAPK. Breast Cancer Res. Treat. 113, 371-376.

15. Huh, J. W., Y. H. Kim, D. S. Kim, S. J. Park, S. R. Lee, S. H. Kim, E. Kim, S. U. Kim, M. S. Kim, H. S. Kim, and K. T. Chang Kim. 2010. Alu-derived old world monkeys exonization event and experimental validation of the LEPR gene. Mol. Cells 30, 201-210.

16. International Human Genome Sequencing Consortium. 2010. 
Initial sequencing and analysis of the human genome. Nature 409, 560-921.

17. Rhesus Macaque Genome Sequencing and Analysis Consoritum. 2007. Evolutionary and biomedical insights from the rhesus macaque genome. Science 316, 222-234.

18. Johnstone, L. S., S. J. Graham, and M. A. Dziadek. 2010. STIM proteins: integrators of signalLung pathways in development, differentiation and disease. J. Cell Mol. Med. 14, 1890-1903.

19. Jurka, J. 2000. Repbase update: a database and an electronic journal of repetitive elements. Trends Genet. 16, 418-420.

20. Lai, F., C. X. Chen, K. C. Carter, and K. Nishikura. 1997. Editing of glutamate receptor $\mathrm{B}$ subunit ion channel RNAs by four alternatively spliced DRADA2 double-stranded RNA adenosine deaminases. Mol. Cell Biol. 17, 2413-2424.

21. Landry, J. R. and D. L. Mager. 2003. Functional analysis of the endogernous retrovirol promoter of ger human ednothelin D receptor gene. J. Virol. 77, 7459-7766.

22. Lin, L., P. Jiang, S. Shen, S. Sato, B. L. Davidson, and Y. Xing. 2009. Large-scale analysis of exonized mammalian-wide interspersed repeats in primate genomes. Hum. Mol. Genet. 18, 2204-2214.

23. Locke, D. P. and et al. 2011. Comparative and demographic analysis of orang-utan genomes. Nature 469, 529-533.

24. McClintock, B. 1950. The origin and behavior of mutable loci in maize. Proc. Natl. Acad. Sci. USA 36, 344-55.

25. Mersch, B., N. Sela, G. Ast, S. Suhai, and A. Hotz-
Wagenblatt. 2007. SERpredict: detection of tissue- or tumor-specific isoforms generated through exonization of transposable elements. BMC Genet. 8, 78.

26. Mills, R. E., E. A. Bennett, R. C. Iskow, and S. E. Devine. 2007. Which transposable elements areactive in the human genome? Trends Genet. 23, 183-191.

27. Modrek, B. and C. J. Lee. 2003. Alternative splicing in the human, mouse and rat genomes is associated with an increased frequency of exon creation and/or loss. Nat. Genet. 34, 177-180.

28. Osorio, A., A. Barroso, M. J. Garca, B. Martnez-Delgado, M. Urioste, and J. Bentez. 1999. Evaluation of the BRCA1 interacting genes RAP80 and CCDC98 in familial breast cancer susceptibility. Breast Cancer Res. Treat 113, 371-376.

29. Portis, J. L. 2002. Perspectives on the role of endogenous human retroviruses in autoimmune diseases. Virology 296, $1-5$.

30. Sin, H. S., J. W. Huh, K. Ahn, H. S. Ha, and H. S. Kim. 2007. Long terminal repeats of human endogenous retrovirus $\mathrm{H}$ family provide alternative polyadenylation signals to NADSYN1 gene. Korean J. Genet. 29, 395-401.

31. Smith, C. W. and J. Valcárcel. 2000. Alternative pre-mRNA splicing: the logic of combinatorial control. Trends Biochem. Sci. 25, 381-388.

32. Sorek, R., R. Shamir, and G. Ast. 2004. How prevalent is functional alternative splicing in the human genome? Trends Genet. 20, 68-71.

\section{초록 : 붉은 털 원숭이의 뇌조직에서 CCDC94 유전자 대체 전사체의 분자적 분석 \\ 윤세은 · 안궁 · 김희수* \\ (부산대학교 생명과학과)}

붉은 털 원숭이의 유전체는 인간의 것과 $93 \%$ 정도로 동일하여, 진화적 연구 및 생물의학적 연구에 널리 활용 되고 있다. 숙주 개체 내로 가동성 유전인자(TEs)의 삽입은 유전자 전사체의 다양성과 발현양상을 다르게 만든다. 본 연구에서는 붉은 털 원숭이의 뇌 조직으로부터 만든 $\mathrm{cDNA}$ 라이브러리에서 112 개 전사체를 동정하여 분석하 였다. 하나의 전사체 R54는 인간과 원숭이의 다양한 조직에서 유전자 발현양상을 비교분석 해 본 결과 서로 다른 패턴을 보여 주었다. 이러한 현상은 가동성 유전인자인 $\mathrm{L} 2 \mathrm{~A}$ 의 삽입으로 인한 스플라이싱 도너 사이트가 변화된 것으로 생각된다. 따라서, 영장류의 진화과정에 있어 유전체 내로 TEs의 삽입은 전사체의 다양성과 유전자 발현 조절에 변화를 주는 것으로 시사된다. 